\title{
2011年大津波による福島県岩間佐糠海岸 における砂州の大変形と津波被害
}

\author{
宇多 高明 1 - 星上 幸良 2 - 野志 保仁 3 - 酒井 和也 4 \\ 1正会員（一般財団）土木研究センター常務理事なぎさ総合研究室長 \\ 兼日本大学客員教授理工学部海洋建築工学科（干110-0016 東京都台東区台東1-6-4） \\ E-mail:uda@pwrc.or.jp \\ 2正会員 国際航業株式会社第一技術部（广183-0057東京都府中市晴見町2-24-1） \\ E-mail: yukiyoshi_hoshigami@kk-grp.jp \\ 3正会員 （有）アイコムネット環境コンサルティング部 \\ （テ101-0054＼cjkstart東京都千代田区神田錦町3-16-11エルヴァージュ神田錦町4F） \\ E-mail:noshi@icomnet.jp \\ 4正会員（一般財団）土木研究センターなぎさ総合研究室（†110-0016 東京都台東区台東1-6-4） \\ E-mail:sakai@pwrc.or.jp
}

\begin{abstract}
2011年3月 11 日午後2時46分, 牡鹿半島の東南東130 km沖を震源地とするマグニチュード9.0の大地震 (東北地方太平洋沖地震) が発生した。この地震に伴い，三陸沿岸をはじめとする太平洋沿岸に大津波が 襲来した。本研究では，福島県南部の岩間佐糠海岸を対象として，津波前の2010年5月29日と，津波後の 2011年5月30日に実施した現地踏査時の現地写真より, まず津波による砂州の変化を明らかにし，その上 で海岸護岸の破壊状況と津波浸水深の調查結果について述べた. さらに砂州の変化状況については2011年 12月27日にも追加調査を行い，その後の砂州の変形状況を調べた.
\end{abstract}

Key Words : 2011 Great Tsunami, Iwama-sanuka coast, inundation, shoreward sand transport, shoreline change

\section{1. まえがき}

2011年3月11日午後2時46分，牡鹿半島の東南東130 km 沖を震源地とするマグニチュード9.0の大地震（東北地 方太平洋沖地震) が発生した。 この地震に伴い，三陸沿 岸をはじめとする太平洋浻岸に大津波が襲来し，甚大な 被害をもたらした．津波後，東日本沿岸における津波痕 跡高を調べるために合同調査団が組織され，このグルー プにより東日本沿岸における詳細な津波高の分布が調べ られた ${ }^{2)}$. 津波は福島県沿岸をも襲い，福島県南部を 流れ，太平洋に注ぐ鮫川の河口北側に位置する岩間佐糠 海岸でも大きな被害が出た（図-1参照）。過去，鮫川は 河口部において北向きに大きく蛇行して太平洋に注いで いたが，常磐共同火力勿来発電所の建設に伴って導流堤 が設置された結果，導流堤に沿って直線的に海へ注ぐよ うになっだ)。この結果, 旧右岸砂州は旧河道を挟んで 沖合に取り残された。この旧右岸砂州は一種の防波堤の 役割を果たしていたが，大津波により大きく変形した.
同時に，砂州背後に延びていた海岸護岸のパラペットが 破壊されたために大量の海水が陸地になだれ込み，大き な被害が出た。佐藤ら ${ }^{4)}$ は，当海岸を対象として流出家 屋と屋根が残された家屋の分布や，破壞された護岸の状

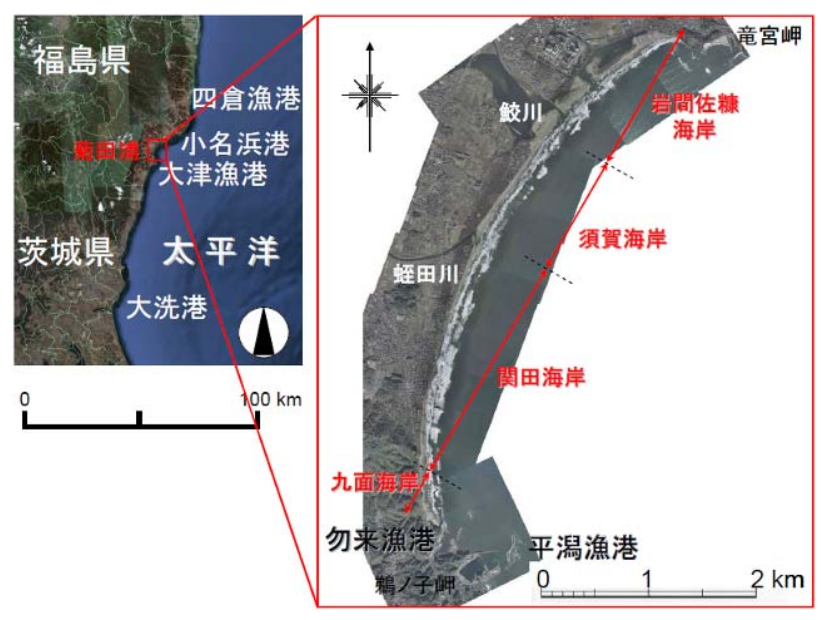

図-1 福島県の岩間佐糠海岸の位置 
況を津波前後の空中写真の比較によりを示した. この研 究は，緊急調査として行われたため，被災の具体的状況 や津波高の分布まで測定されていなかった。本研究では, 津波前の2010年5月29日と，津波後の2011年5月30日に実 施した現地踏査時の現地写真より，まず津波による砂州 の変化状況を明らかにし，その上で海岸護岸の破壊状況 と津波浸水深の調查結果について述べる。なお，測定地 点はGPSにより，また標高は地震津波を受けたものの倒 壊せずに残された護岸（2箇所）を基準としてレ心゙ルで 測量し, 後に当海岸の地盤沈下量 $0.5 \mathrm{~m}$ 考慮して補正 した. また, 砂州の変化状況については2011年12月27日 にも追加調査を行い，その後の砂州の変形状況を調べた.

\section{2. 津波による旧鮫川右岸砂州の流出とその後の 変形}

津波襲来前の2010年5月29日には，図-2に示すように 海岸沖に旧鮫川右岸砂州が伸びていた. 野志ら゙)が示し たように，この砂州の構成材料は細砂中砂であり，それ らの含有率は細砂 $37.2 \%$, 中砂 $62.8 \%$ であった. 図-2の 矢印Aは砂州上に残された微高地（浚渫土砂が盛り上げ られたもの）で，その頂部は植生帯で覆われていた。 ま た，この微高地Aの手前（北）側には高波浪時の砂州越 流によって岸向きに旧河道へと運ばれた砂が細長く堆積 していた．このような砂州が，2011年5月30日には，図3に示すように微高地Aを残してその北側の砂州は大き く変形し, 砂量が減少しつつ岸向きに運ばれた. 一方, 矢印Bで示寸海岸護岸は全壊したが, 護岸と平行に敷き 並べられてあった中空三角ブロックはほぼ原位置を保っ た. 微高地Aは周辺と比べて標高がわずかに高かったた め津波力が削がれ，同時に砂州上部が密生した植生帯で 守られていたため, 砂州の岸側には砂は運び込まれなか った. しかし，その北側では砂州が侵食され砂が岸向き に運ばれた.この砂州は中砂細砂で構成されていたが, 粒径が小さいため津波時の流動によって大きく移動する ことになった．図-2，3に示寸津波前後における旧右岸 砂州の変形は, 砂が津波作用により岸向きに運ばれたこ とを示している．津波の戻り流れによる海浜の侵食の例 は仙台湾の荒浜海岸で観察された5が，岩間佐糠海岸は 砂が岸向きに運ばれた典型事例であった，その理由には， (1)津波の戻り流れにより砂が沖合へと運ばれて海浜土砂 量が損失したこと, (2)地震後約0.5 mの地盤沈下により 砂浜を形成していた砂量が減少したことが関与し, 海浜 が元の場所では不安定となり, 水深の小さい場所へと移 動して安定化したことが指摘できる.この砂州は，その 後も変形を続け，2011年12月27日には図-4に示す状態と なった．図には砂州に残されていた微高地Aの位置も記
入してある. その位置は, 発電所の排水口沖の導流堤と の相対位置関係から定めた。津波前，図-2に示したよう に汀線はAより海側にあったが，12月27日の踏査では微 高地Aは侵食されて完全に消失し, 汀線形状は直線状と なった. このように砂州は波の作用下で陸側に押し付け られるように変形したことが分かった。

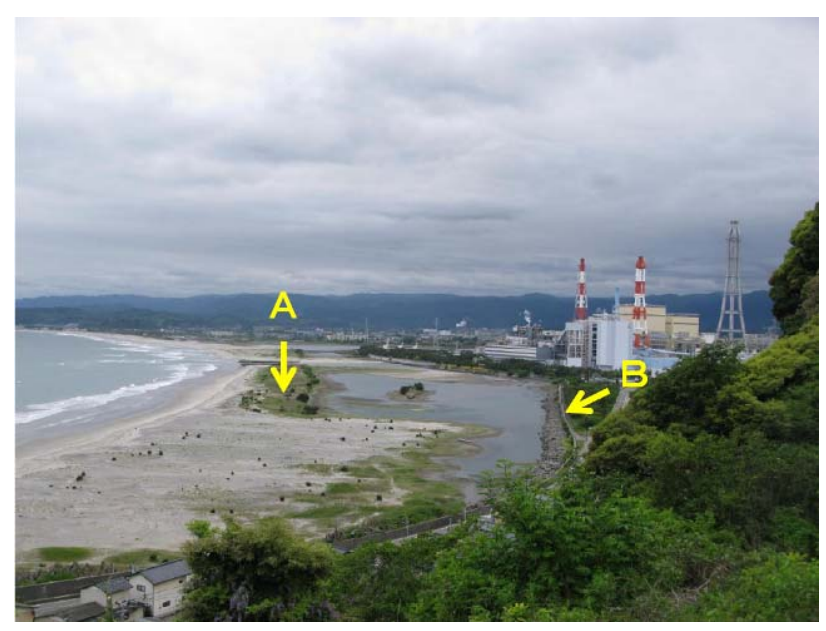

図-2 岩間佐棣海岸沖の砂州状況（2010年5月29日撮影）

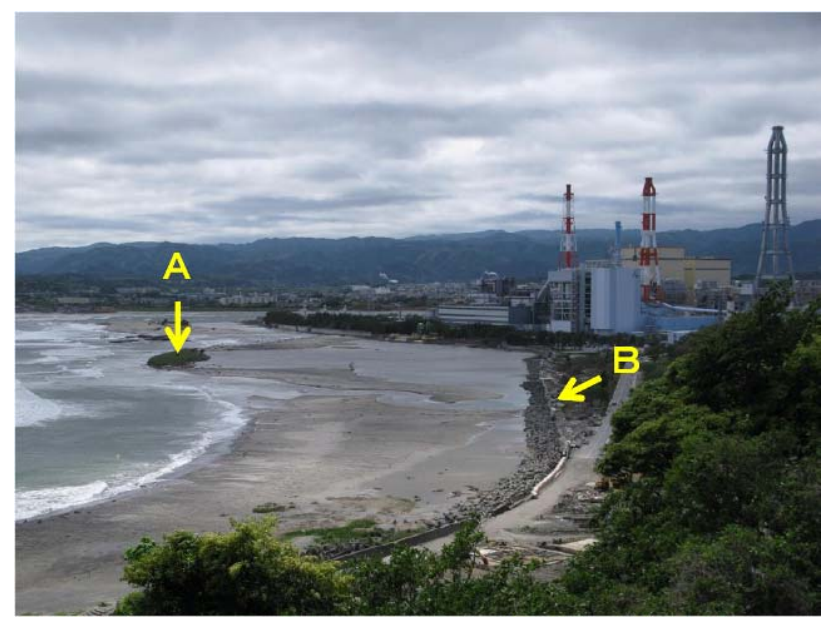

図-3 岩間佐棣海岸沖の砂州状況（2011年5月30日撮影）

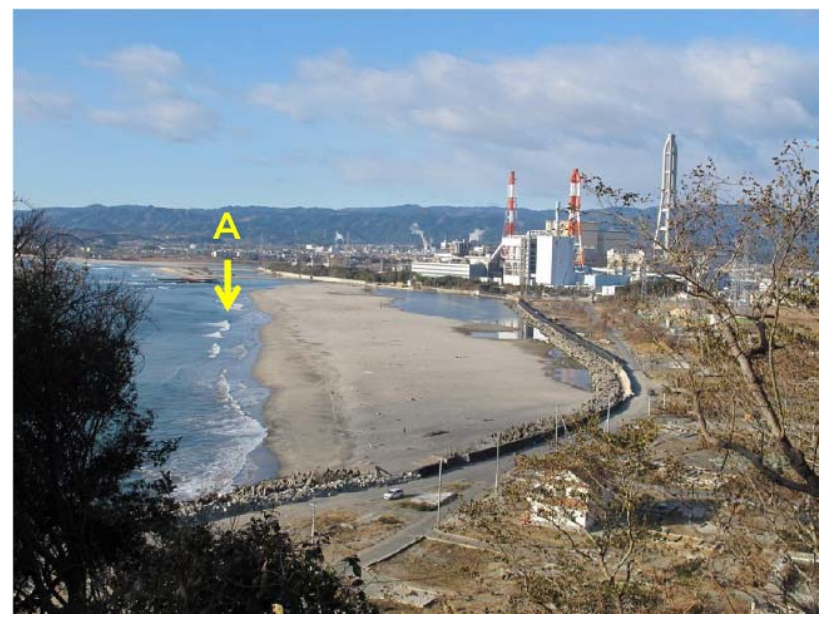

図-4 岩間佐棣海岸沖の砂州状況（2011年12月27日撮影） 


\section{3. 津波浸水深の測定}

岩間佐糠海岸では，大津波により大きな被害が出たが, 2011年5月30日には個々の家屋の被災状況を調べるとと もに，浸水深の調査を行った。この結果14地点において 津波痕跡を確認寸ることができた．2011年3月12日撮影 の衛星画像（図-5）には写真撮影地点の番号を示す。ま た，図-6は国土地理院により2011年7月12日に撮影され た斜め写真に調査地点を落としたものである．図-5, 6 に示すように，周辺に津波痕跡が残されていた家屋は台 地の下部に沿って帯状に並んでいたものがほとんどで, 竜宮岬の陰の外側では全壊して津波痕跡を見出すのが困 難な状態であった.

図-5に示す14地点のうち代表7地点での被害状況は次 のようである。まず，地点2では，図-7のように家屋の 一階は全壊していたが，二階のガラス空は無傷のまま残 されていた. したがって津波痕跡は一階と二階の中間に あることになるが，一階の屋根の左端（海側）付近で瓦
がめくれており，瓦に鉛直上方の力が加わったと見られ ることから，図-7に示寸破線の高さが津波痕跡と推定さ れた。 この場合，津波の高さは地盤面上 $3.0 \mathrm{~m}$ (T.P.+6.1 m)であった。 なお，二階の瓦も変形しているが，二階 のガラス空が無傷で残されていることから，二階の瓦は 津波ではなく地震動によるものと推定される。また，一 階の屋根瓦のめくりあがりは以下で述べる地点4, 6, 7, 9 で共通的に見られた現象であった。

地点 4 では，地点2と同様図-8のように一階は津波が貫 いていたが，再び屋根瓦にめくりあがりが生じており， このことから津波の浸水深は地上3.6 m(T.P.+5.8 m) と推 定された，家屋も一階は全壊状態にあり空は流失してい たが，津波に対してほとんど抵抗しないカーテンはその まま残された．地点6では，図-9のように一階建ての建 物の瓦莫屋根がほぼ全部流失しており，地盤からわずか に瓦が残された部分までの高さは地上 $3.9 \mathrm{~m}($ T.P.+7.3 m) であった．またこの家屋では，海側から家屋へと侵入し た津波は裏側から流出したため側面にある玄関は流失し

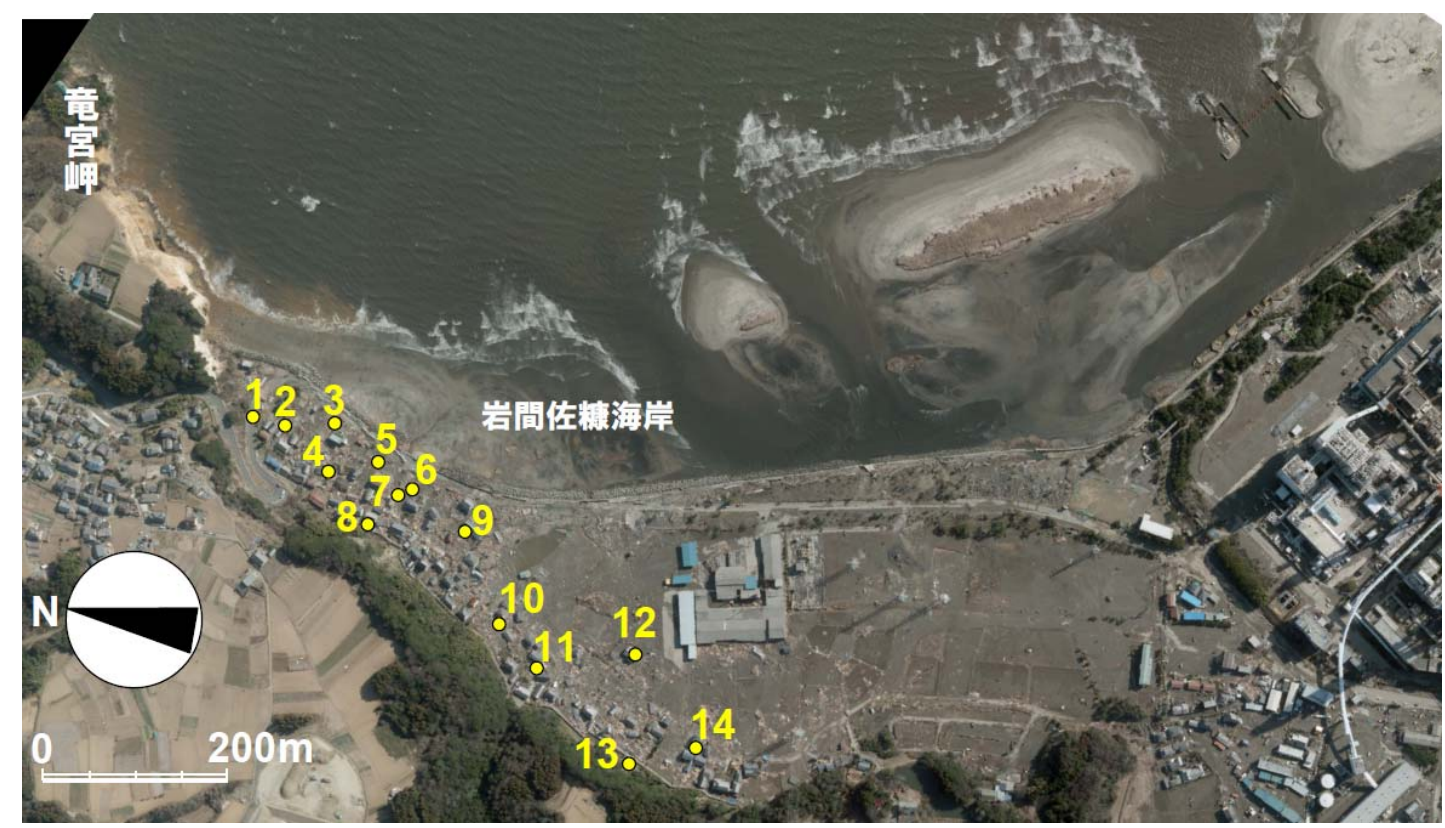

図-5 岩間佐栤海岸の空撮写真（2011年3月12日国土地理院撮影）と測点No.1 N No.14の位置

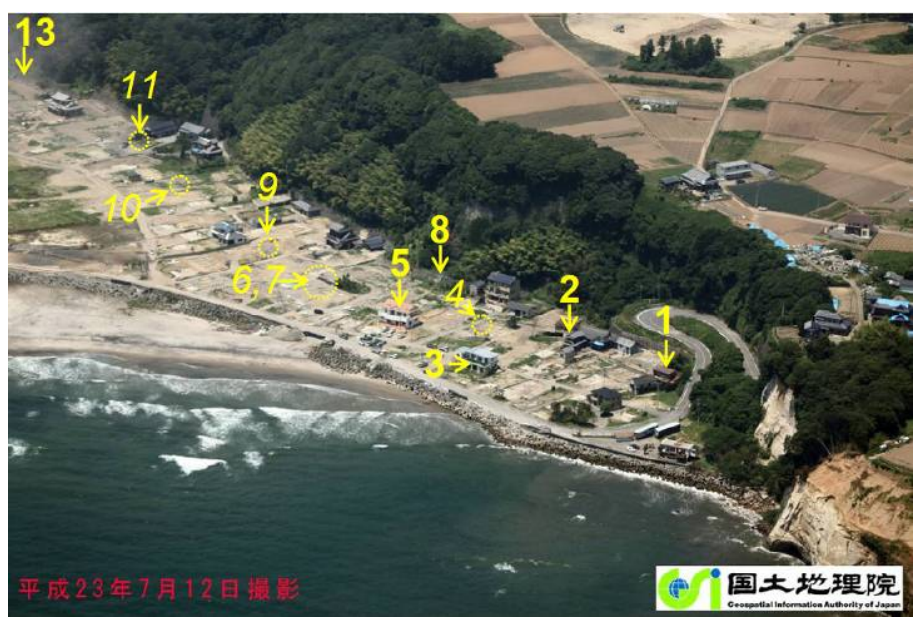

図-6 岩間佐棣海岸の斜め写真（2011年7月12日,国土地理院撮影） 


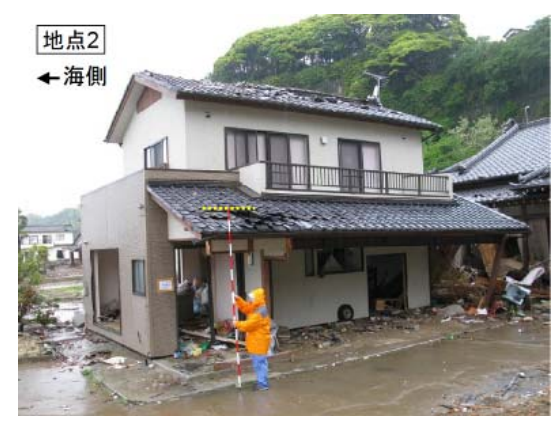

図-7 地点 2 の家屋の屋根に残された津波 痕跡

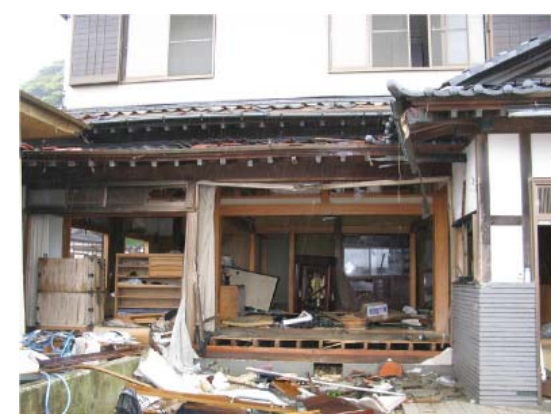

図-10 地点 6 の家屋に並んで建つ家屋の 被災状況

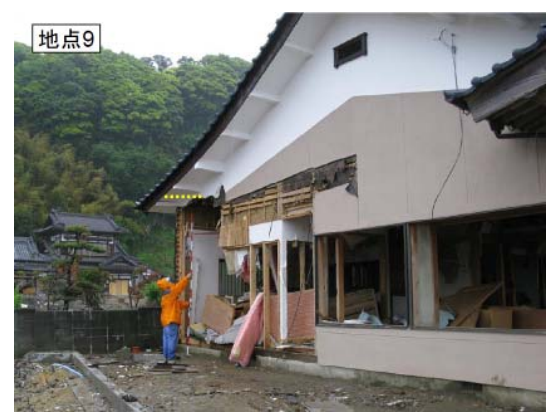

図-13 地点 9 の家屋の側壁の破壊状況

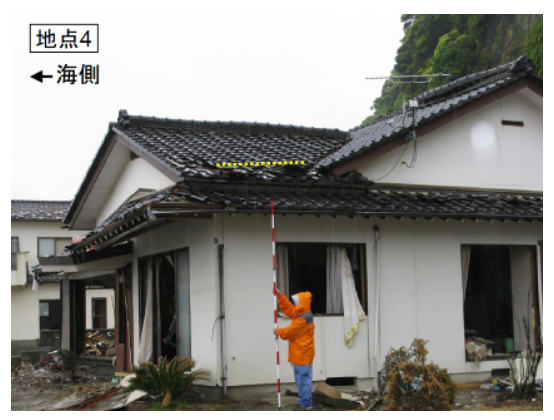

図-8 地点 4 の家屋の屋根に残された津波 痕跡

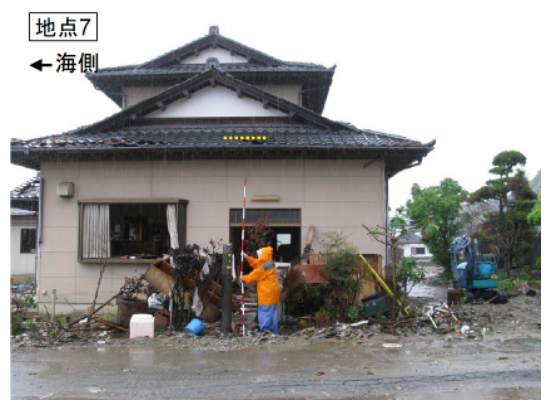

図-11 地点 7 の家屋の屋根に残された津 波痕跡

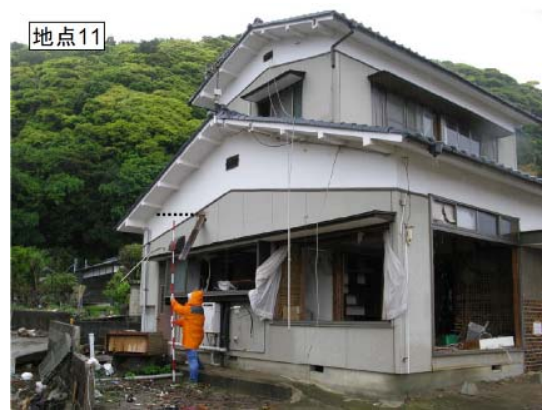

図-14 地点 11 の家屋の側壁の破壊状況

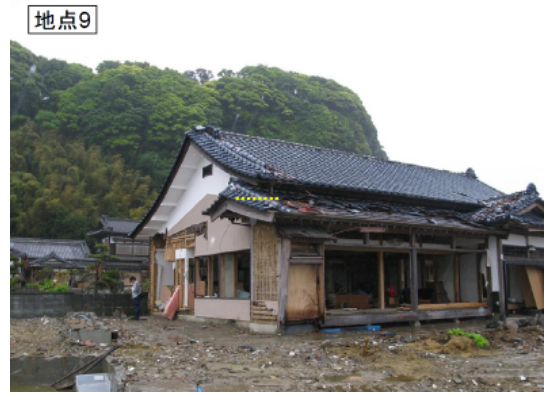

図-12 地点 9 の家屋の屋根に残された津 波痕跡

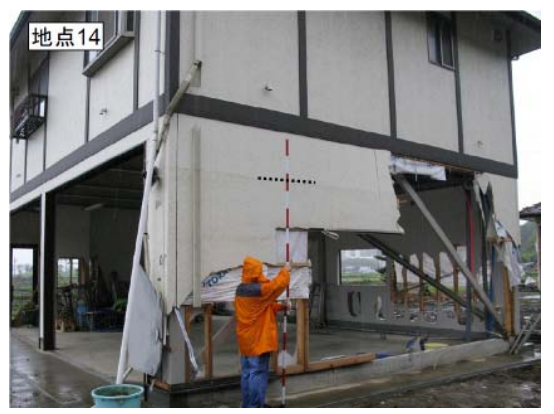

図-15 地点 14 の家屋側壁に残された津波 痕跡
大きな穴が残された. このことから津波は洪水時のよう に浸水深が徐々に上昇するのではなく, 強大な運動量を 持った水隗が家屋を突き抜けるという特徵を有していた ことが分かる．図-10は，図-9に示す家屋の右側の家屋 の被災状況を示す。ここでは一階の壁は壊され家財道具 が流されていたが，二階のガラスは無傷で残されていた。

図-11に示す地点7でも屋根瓦のめくれ上がりが生じ, その高さは地上3.7 m(T.P.+8.1 m)にあった. 同様に図-12 は地点9の状況を示す. 家屋の右手前が海側である.こ こでも一階建ての建物の屋根瓦のめくれ上がりが生じ, 破線位置の標高はT.P.+7.8 mであった.この建物では側 面の壁も剥がれ落ちていることから津波襲来時一階が完 全水没するような浸水深であり，その後側面を突き破っ て津波が流出したと推察される. 同じ建物の側面を示す のが図-13であるが，ここでの浸水深は地上 3.4 m(T.P.+7.4 m)であった. さらに, 地点11では, 図-14の ように一階の側壁に流木が突き刺さっていることから, これが津波の浸水深を与えると見られ, その高さは地上
3.1 m(T.P.+7.2 m)にあった. 二階のガラス空がそのまま 残されているのに対し一階が完全破壊状態にあり, 両者 がよい対応を示す. 最後に，地点14では鉄骨モルタル製 の家屋の一階部分が全壊していたが，図-15に示すよう に家屋の壁には地上2.6m(T.P.+6.1 m)の水位痕跡が見出さ れた. 家屋の正面, 側面, 裏面には津波が貫通したため 大きな穴が残されていた。

表-1には，現地で確認された14地点の地盤高, 浸水深, および津波痕跡を一括して示す. 測定地点の地盤高が高 い地点1と地点11を除いた11地点での浸水深の平均值は $3.4 \mathrm{~m}$, 最大值は4.0 mであった。この值はちょうど家屋 の一階を水没する深さである。 また，最大津波痕跡高は 地点8で遡上高として測定されたT.P.+10.2 mであった. また家屋周辺での浸水深として測定された津波高の最大 值は，地点7のT.P.+8.1 mであった．岩間佐糠海岸の護岸 高は，北端から約210 m区間ではT.P.+5.8 m, これに続く 約310 m区間ではT.P.+4.6 mであったが，津波高は護岸の 天端高をはるかに超える高さであった. 


\section{4. 海岸護岸の破壊}

岩間佐棣海岸の護岸は, 当初河川護岸として築造なら びに嵩上げがなされたが（建設時期は不明），現在は岩 間佐糠海岸の護岸として管理されている. 護岸の配置と しては，北端から約210 m区間は天端高がT.P.+5.8 m，根 固め消波工の重量は4 t, これに続く約310 m区間では天 端高がT.P.+4.6m，根固め消波工の重量が5 $\mathrm{t}$ ，さらにその 南側約480 m区間での護岸天端高はT.P.+4.6 m, 根固め消 波工の重量は2 tであった。 これらのうち常磐共同火力勿 来発電所北端から旧河口（北端）までの約900 m区間で の護岸破壊が著しかった.

図-16は，遠方に常磐共同火力勿来発電所を望みつつ岩 間佐糠海岸の破堤箇所を示寸，護岸に沿って設置された 中空三角ブロックはほぼ原形を保っていたが，護岸は倒 壊し, 破断されたコンクリート檴岸の一部が津波により 陸側に運ばれたことが分かる。ほぼ同じ場所において護 岸の表のり面の破断状況を撮影したのが図-17である.

厚さ約 $30 \mathrm{~cm}$ 表のり面がきれいに破断し，陸側に運ば れていた．撮影方向を南から北へと反転し, 海岸護岸の 破壊状況を北向きに撮影したのが図-18である.ここで も現地盤から突出した部分はきれいに破断し，破壊され た護岸が陸側に運ばれていた．護岸の破断面の幅は約2 mであり，基礎として敷設されていた碩層が露出してい た.

図-19は陸側に運ばれた護岸の一部を示すが，運ばれ た堤体が90 回転していることを考慮すれば，護岸の破 断面の幅はほぼ2mであり, 図-18に示寸敷幅とほぼ一致

\begin{tabular}{c|c|c|c}
\multicolumn{3}{c}{ 表-1 福島県岩間佐糠海岸の津波痕跡高 } \\
\hline 地点No. & $\begin{array}{c}\text { 地盤高 } \\
\text { (T.P. m) }\end{array}$ & $\begin{array}{c}\text { 浸水深 } \\
\text { (m) }\end{array}$ & $\begin{array}{c}\text { 津波痕跡高 } \\
\text { (T.P. m) }\end{array}$ \\
\hline \hline 1 & 6.3 & 1.4 & 7.7 \\
\hline 2 & 3.1 & 3.0 & 6.1 \\
\hline 3 & 3.9 & 3.2 & 7.1 \\
\hline 4 & 2.2 & 3.6 & 5.8 \\
\hline 5 & 2.8 & 4.0 & 6.8 \\
\hline 6 & 3.4 & 3.9 & 7.3 \\
\hline 7 & 4.4 & 3.7 & 8.1 \\
\hline 8 & - & - & 10.2 (遡上) \\
\hline 9 & 4.0 & 3.4 & 7.4 \\
\cline { 2 - 4 } & - & - & 7.8 \\
\hline 10 & 3.3 & 3.8 & 7.1 \\
\hline 11 & 4.1 & 3.1 & 7.2 \\
\hline 12 & 3.2 & 3.1 & 6.3 \\
\hline 13 & 5.7 & 1.0 & 6.7 \\
\hline 14 & 3.5 & 2.6 & 6.1 \\
\hline & & &
\end{tabular}

する．また図-18では護岸の破断面の陸側には礫が敷き 詰めてあったが，図-19の転倒した護岸の底にはコンク リート面に多数の磼が付着していることから，基礎とし ての䃯層上にコンクリートが打設されて護岸が造られた ことが明らかである.さらに北側では，護岸の表のり面 の破断面に図-20の状況が見られた．表のり面に穴が開 いており，その中央に腐食した木杭が残されていたので ある.この木杭穴は, 沿岸方向に一定間隔で並んでおり

(図-20の矢印C参照)，コンクリート打設時に型枠を 固定するために使われたもので，この護岸が古い時代に 造られたことを示している．また，その北側では図-21

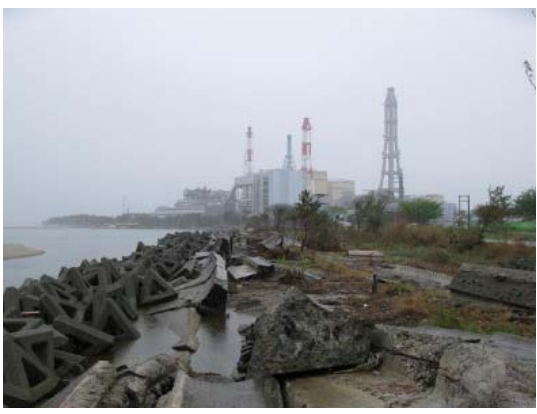

図-16 常磐共同火力勿来発電所を望夕つ つ岩間佐糠海岸の破堤箇所を撮影

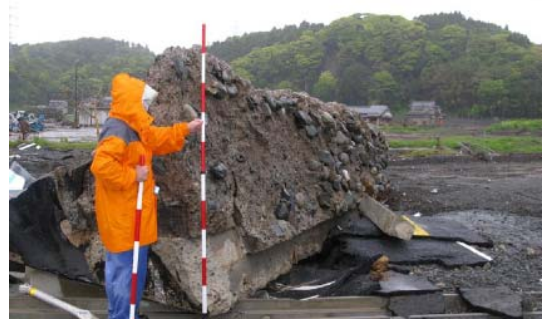

図-19 陸側に運ばれた護岸の底

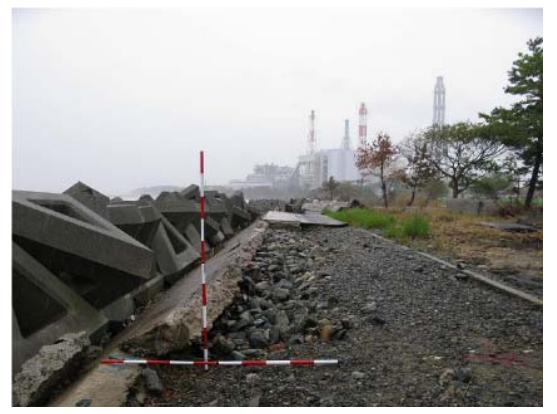

図-17 護岸の表のり面の破断状況

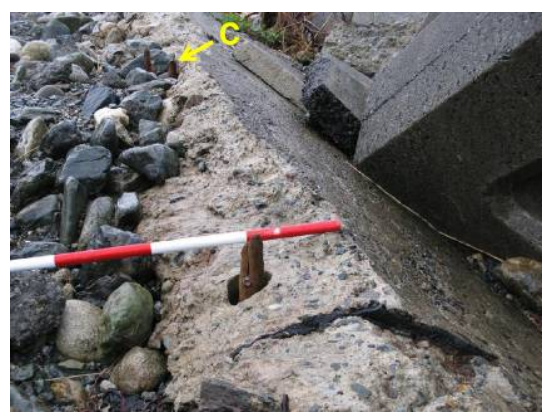

図-20 護岸の表のり面の破断面

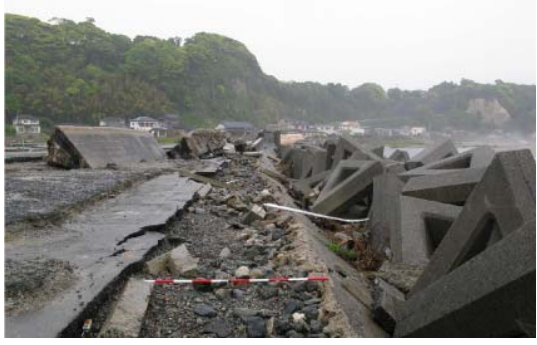

図-18 北向きに海岸護岸の破壊状況を撮影

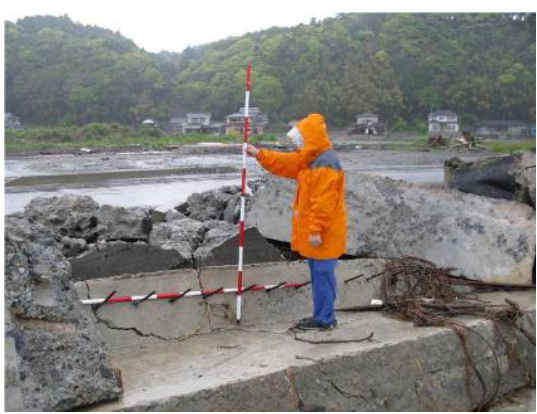

図-21 護岸の根継ぎのために挿入された約 $0.3 \mathrm{~m}$ 間隔の鉄筋 


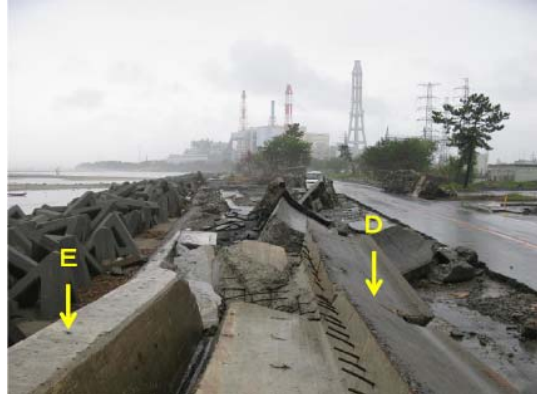

図-22 多数の鉄筋の突出 (D) と多数の穴 $(\mathrm{E})$

のように，護岸の根継ぎのために新設のコンクリートを 約 $0.3 \mathrm{~m}$ 間隔に並んだ鉄筋で固定する手法が取られてい たが，佐藤ら ${ }^{4)}$ 指摘したように，それがそのまま抜け ていた．図-22も同様な状況を示すが，多数の鉄筋が突 出しているコンクリートDは左端のコクリートEの上に 載せられており，そのためEには多数の穴が残されてい る. 護岸Eの上に載せられるようにして護岸の嵩上げが 行われたが，それが90後側に回転して陸側に落ち込ん だことが分かる，その場合，鉄筋がそのまま抜けており 変形もしていないことから，護岸D, Eは十分固着せず, ただ載せられた状態に近かったと推定される．また，同 じ地区の調査で，佐藤ら ${ }^{4}$ は，堤防の破壊は，地盤面と 同じ位置にある海側のコンクリートの打ち継ぎ目で生じ ているものが多く，鉄筋（径16 mm，挿し筋の長さは30 cm程度）は引つ張り破断しているか, 抜け出している ものが多かったとしている.

\section{5. まとめ}

海岸堤防などの防護施設は，発生頻度が低いL2レベ ルの大津波に対して防護を期待するものではなく，より 高頻度で発生するL1津波時に海岸部にある財産を守り， 人々の避難の助けとなることを期待するものではある.
しかし，大津波のエネルギーを幾分でも削ぐことができ れば避難時の助けとなる機能は依然として期待される ${ }^{1)}$. このようなことから，各地の海岸に過去から設置されて きた堤防護岸が機能を発揮できるように健全に保つこと は大事なことである，岩間佐糠海岸の護岸の被災状況に よれば，護岸の製作方法から考えて昭和30,40年代に造 られたものや，古い護岸を基礎としてその上に根継ぎさ れたものがほとんどであった．現在の護岸の築造基準に 合わない上記と同様な構造を有する施設は全国各地にあ ると考えられ，さらに建設後数十年が経過して空洞化や 老朽化が進んでいることを考慮すれば，このような護岸 の防護性能をいかにして保つかが今後大きな課題となる と考えられる. また，護岸状況を外側から点検してもこ こで明らかにしたような構造上の弱点は明らかにするこ とが難しいと考えられるので，空洞化や老朽化した堤 防・護岸について代表箇所の破壊検査を行うことによる 施設の信頼性確保も必要と考えられる.

\section{参考文献}

1) Shibayama, T. : Field survey of the 2011 off the Pacific Coast of Tohoku Earthquake Tsunami disaster and future tsunami protection, Proc. 6th Inter. Conf. on Asian and Pacific Coasts, pp. 79-82, 2011.

2) Tohoku Earthquake Tsunami Joint Survey Group, 2011. http://www.coastal.jp/tsunami2011/.

3) 野志保仁・宇多高明・星上幸良・田村憲史：福島県 の鮫川河口を含む竜宮岬〜勿来漁港で起きつつある 海浜変形, 土木学会論文集 B2（海岸工学），Vol.67, No.2, I_536-I_540, 2011.

4) 佐藤愼司, 武若聡, 劉海江, 信岡尚道 : 2011 年東北地方 太平洋沖地震津波による福島県勿来海岸における被 害, 土木学会論文集 B2 (海岸工学), Vol. 67, No.2, pp.I_1296-I_1300, 2011.

5)（一般財団）土木研究センターなぎさ総合研究室 : 東日本大震災津波災害状況調査, http://pwrc-nagisa.jp, 2011.

\title{
DEFORMATION OF SADY BEACH AND INUNDATION ON IWAMA-SANUKA COAST IN FUKUSHIMA PREFECTURE DUE TO THE 2011 GREAT TSUNAMI
}

\author{
Takaaki Uda, Yukiyoshi Hoshigami, Yasuhito Noshi and Kazuya Sakai
}

A massive earthquake with a magnitude of 9.0 occurred on March 11, 2011, at 14:46 with an epicenter $130 \mathrm{~km}$ offshore of Oshika Peninsula in Miyagi Prefecture. After the earthquake, a large tsunami was generated owing to the abrupt crustal subsidence and elevation and inundated east Japan's coastline. We carried out field observations to investigate the deformation of the previous river mouth bar by the comparison of oblique photographs as well as the investigations of the damage of the seawalls and tsunami inundation depth on the Iwama-sanuka coast, located north of the Same River in the southern Fukushima Prefecture. The results of the field observations on the deformation of sandy beach and the inundation of the Iwama-sanuka coast were reported. 